\title{
Eksekusi Putusan Tindak Pidana Lingkungan Hidup Terkait Limbah Bahan Berbahaya Beracun (B3)
}

\author{
Ika Mauluddhina \\ ikamauluddhina@yahoo.com \\ Universitas Airlangga
}

\begin{abstract}
The execution of a judge's decision in an environmental crime related to waste B-3 so that pollution does not occur again is not clearly stipulated in the legislation. Where this must meet the criteria to ensure the sustainable use of living things and their ecosystems. From developing countries to developed countries, toxic hazardous material (B3) waste starts to prove to cause problems because it can endanger the environment. The problem that often arises is regarding the implementation of court decisions that have permanent legal force carried out by the Prosecutor as the executor. How the execution and costs of execution have not been regulated in a comprehensive legislation. The problem of the large cost of processing B-3 waste in developed countries may not be a problem because it is clear that strict compliance and law. Conversely, the absence of costs in the destruction of B-3 waste in developing countries that are evidence in the court will lead to weak law enforcement. On the other hand, if the B3 is confiscated to be destroyed, it will cause back contamination in Indonesia. The existence of B-3 waste import exports between developed countries and developing countries may be said to have lasted long enough until the revival of international community awareness of the dangers of pollution of industrial waste. Analysis of several decisions by judges on environmental crimes may cause pollution again in Indonesia. The verdict of a case for an environmental crime related to proof of import of B-3 waste should be re-exported back to the country of origin with the cost of the impoter or the defendant not being confiscated or destroyed.
\end{abstract}

Keywords: B-3 Waste Execution; Evidence case of B-3; Environmental Pollution Again.

\begin{abstract}
Abstrak
Eksekusi putusan hakim dalam tindak pidana lingkungan hidup terkait limbah Bahan Berbahaya Beracun (B-3) agar tidak terjadi pencemaran hidup kembali tidak diatur jelas dalam perundangundangan. Dimana hal tersebut harus memenuhi kriteria menjamin keberlanjutan pemanfaatan dari makhluk hidup dan ekosistemnya. Dari negera berkembang sampai dengam negara maju limbah bahan berbahaya beracun (B3) mulai terbukti menimbulkan masalah karena dapat membahayakan lingkungan hidup. Masalah yang seringkali timbul adalah mengenai pelaksanaan putusan pengadilan yang mempunyai kekuatan hukum tetap yang dilakukan oleh Jaksa selaku eksekutor. Bagaimana cara pelaksanaan dan biaya eksekusi belum diatur dalam peraturan perundang-undangan secara komphrehensif. Masalah besarnya biaya pengolahan limbah B-3 di negara-negara maju mungkin tidak menjadi masalah karena sudah jelas penaatan dan hukum yang tegas. Sebaliknya, tidak adanya biaya dalam pemusnahan limbah B-3 di negara-negara berkembang yang menjadi barang bukti di peradilan akan menyebabkan lemahnya penegakan hukum. Di sisi lain, bila B3 tersebut dirampas untuk dimusnahkan akan menimbukan pencemaran kembali di Indonesia. Keberadaan ekspor impor limbah B-3 antara negara maju dengan negara berkembang boleh dikatakan sudah berlangsung cukup lama sampai munculnya kembali kesadaran masyarakat internasional terhadap bahaya dari pencemaran limbah industri tersebut. Analisis beberapa putusan hakim perkara tindak pidana lingkungan terkait barang bukti perkara impor limbah B-3 masih menimbulkan pencemaran lingkungan hidup kembali di Indonesia, seharusnya adalah direekspor kembali ke negara asal dengan biaya dari importir atau terdakwa bukan dirampas atau dimusnahkan.
\end{abstract}

Kata Kunci: Eksekusi Limbah B-3; Perkara Barang bukti B-3; Pencemaran Lingkungan Hidup Kembali. 


\section{Pendahuluan}

Hukum Lingkungan mencakup penataan dan penegakan hukum (compliance and enforcement), yang meliputi bidang hukum pidana, hukum perdata dan hukum administrasi negara. Secara terminologi istilah penataan mempunyai arti tindakan preemtif, preventif dan proaktif. Penegakan mempunyai arti tindakan represif. Apalagi diformulasikan antara preventif dengan represif maka akan berwujud berupa sanksi. Pada hakekatnya hukum lingkungan lebih menekankan pada nilai-nilai penataan hukum terhadap pelestarian fungsi lingkungan hidup, dibandingkan pada nilai nilai penegakkan hukumnya. Nilai nilai penataan hukum harus diberi bobot yang kuat dan harus dapat diformalkan ke dalam peraturan perundang-undangan. ${ }^{1}$

Permasalahan hukum lingkungan hidup yang tumbuh dan berkembang dalam masyarakat semakin kompleks, sehingga memerlukan regulasi yang secara komprehensif dan integral mampu digunakan sebagai pijakan dalam melaksanakan penegakan hukum. Mencermati perkembangan tersebut, maka perlu suatu upaya untuk menyempurnakan Undang-Undang Nomor 4 Tahun 1982 jo Undang-Undang Nomor 23 Tahun 1997 yang diperbaharui oleh Undang-Undang Nomor 32 Tahun 2009 tentang Perlindungan dan Pengelolaan Lingkungan Hidup disebut juga UUPPLH yang memiliki tujuan perlindungan dan pengelolaan lingkungan hidup wilayah Negara Kesatuan Republik Indonesia (NKRI) dari pencemaran dan/atau kerusakan lingkungan hidup, tertuang dalam Pasal 3: "menjamin keselamatan, kesehatan dan kehidupan manusia, menjamin kelangsungan kehidupan makhluk hidup dan kelestarian ekosistem, menjaga kelestarian fungsi lingkungan hidup, mencapai keserasian, keselarasan dan keseimbangan lingkungan hidup, menjamin terpenuhinya keadilan generasi masa kini dan generasi masa depan, menjamin pemenuhan dan perlindungan hak atas lingkungan hidup sebagai bagian dari hak asasi manusia, mengendalikan pemanfaatan sumber daya alam secara bijaksana, mewujudkan pembangunan berkelanjutan dan mengantisipasi isu lingkungan global".

${ }^{1}$ Amirudin A. Dajaan Imami, dkk, Asas Subsidaritas: Kedudukan dan Implementasi dalam Penegakan Hukum Lingkungan (PP-PSL FH UNPAD dan Bestar 2009). [3]. 
Undang-Undang Perlindungan dan Pengelolaan Lingkungan Hidup (UUPPLH) lebih menjamin keoastian hukum dan memberikan perlindungan terhadap hak setiap orang untuk mendapatkan lingkungan hidup yang baik dan sehat sebagai bagian dari perlindungan terhadap keseluruhan ekosistem mendasari kebijaksanaan lingkungan di Indonesia. Sifat UUPPLH sebagai payung hukum dari semua peraturan lingkungan yang ada di Indonesia. Persyaratan yang penting untuk melaksanakan kebijaksanaan lingkungan adalah pembinaan peraturan perundang-undangan lingkungan yang tangguh, dipersiapkan secara cermat dengan memperhitungkan unsur keterpaduan dalam sistem pengaturan, sehingga efektivitasnya dapat tercapai secara maksimal. ${ }^{2}$

Penegakan hukum lingkungan merupakan mata rantai terakhir dari siklus pengaturan (regulatory chain) perencanaan kebijakan lingkungan. Rene Sarden \& Michiel Heldeweg sebagaimana dikutip oleh G.H. Addink, ${ }^{3}$ menuliskan ada lima tahap dalam siklus pengaturan perencanaan kebijakan lingkungan, yaitu (1) peraturan perundang-undangan (legislation), (2) penentuan standar standar lingkungan (regulation/setting standard), (3) pemberian izin (licensing/issueing permits), (4) pelaksanaan peraturan (implementation), (5) penegakan hukum lingkungan (environmental law enforcement/control).

Peraturan perundang-undangan lingkungan hidup menempati posisi kunci berhasilnya kebijakan lingkungan di suatu negara, khususnya bagi negara yang menganut sistem hukum Eropa Kontinental seperti Indonesia. Melalui peraturan perundang-undangan inilah diletakkan dasar bagi kebijakan lingkungan dan sekaligus juga merupakan alat yang ada pada pemerintah untuk mewujudkan kebijakan lingkungan. Oleh karena itu lemahnya peraturan perundang-undangan akan menimbulkan kesulitan dalam pelaksanaan penegakan hukum lingkungan.

\footnotetext{
${ }^{2}$ Siti Sundari Rangkuti, Hukum Lingkungan dan Kebijaksanaan Lingkungan Nasional (Airlangga University Press 2015).[119].

${ }^{3}$ G.H. Addink, Penataran Environmental Law and Suistainable Development: Literature, (Fakultas Hukum Universitas Airlangga 1999).[35]; Lihat juga Siti Sundari Rangkuti, Op Cit.[379]; Siti Sundari Rangkuti, "Kesamaan Persepsi Terhadap Penegakan Hukum Lingkungan”, Yuridika, No. 5 Tahun IX September-Oktober 1994, [3, 4]; Muhammad Akib, Hukum Lingkungan, Perspektif Global dan Nasional (Rajawali Pers, Edisi Revisi, Cetakan Kedua, Oktober 2014).[73].
} 
Secara eksplisit, paradigma pengelolaan lingkungan hidup sudah diakomodir dalam konstitusi negara. Dalam Pasal 33 ayat (3) dan (4) UUD 1945, bersifat fundamental dan mendasar. Dengan demikian dapat dikatakan bahwa Konstitusi Indonesia yang memuat kebijakan hukum pengelolaan lingkungan inilah yang disebut Jimly Asshiddiqie prinsip "konstitusi hijau" (green constitution) ${ }^{4}$. Prinsip ini mestinya menjadi ruh yang menjiwai logika legislasi kita sehingga tercipta prinsip "legislasi hijau (green legislation) dalam pembentukan peraturan perundang-undangan.

Tindak pidana lingkungan terkait Bahan Berbahaya Beracun (B3) makin marak terjadi di Indonesia karena era industrialisasi, antara lain ekspor impor limbah Bahan Berbahaya Beracun (B3), dumping (pembuangan) limbah B3, penampungan ilegal limbah B3 atau pengelolaan limbah B3 tanpa izin sudah seharusnya mendapat perhatian lebih dari Pemerintah. Bahkan Indonesia menjadi salah satu negara importir limbah Bahan Berbahaya Beracun (B3) sejak tahun 1991. Salah satu limbah Bahan Bahaya Beracun (B3) yang masih diimpor hingga sekarang adalah aki bekas yang diambil adalah timah hitam yang mempunyai sifat kontaminan yang berbahaya dan beracun. Selain mengimpor aki bekas, Indonesia juga pernah mengimpor limbah plastik, yang didalamnya juga terkirim limbah Bahan Bahaya Beracun (B3) lainnya seperti plasticizier dan sludge serta kemasan B3. ${ }^{5}$ Kasus 113 kontainer berisi besi bekas yang diimpor masuk ke Indonesia lewat beberapa Pelabuhan besar, mengandung limbah Bahan Berbahaya Beracun (B3) yang diambil dari tempat pembuangan sampah yang ada di Inggris dan Belanda tanpa dibersihkan terlebih dahulu padahal terdapat banyak kotoran, diantaranya tanah, oli, karat, plastik, aspal atau kotoran lainnya. Menurut aturan, impor besi bekas harus dibersihkan terlebih dahulu, dan hanya metalnya atau besi yang dibawa. Kemudian Limbah cair diduga mengandung Bahan Berbahaya dan Beracun (B3) yang dibuang di saluran air di dekat Rusun Romo Kalisari juga merupakan limbah

\footnotetext{
${ }^{4}$ Jimly Asshiddiqie, Green Constitution, Nuansa Hijau Undang-Undang Dasar Negara Republik Indonesia Tahun 1945 (Raja Grafindo Persada 2009).[5].

${ }^{5}$ http://www.nasional.tempo.co/berita/baca Indonesia Jadi Importir Limbah B3 dikunjungi pada tanggal 19 Agustus 2018.
} 
yang diimpor dari Korea Selatan. Penanganan kasus impor limbah B3 di Pulau Galang Baru Batam dengan modus operandi mengimpor limbah B3 dengan dalil material organik (kompos) ternyata kandungan logam berat yang terdapat dalam limbah tersebut termasuk dalam Bahan Berbahaya Beracun (B3). ${ }^{6}$ Atas dasar itu, maka penegakan hukum atas limbah Bahan Berbahaya Beracun (B3) harus ditegakkan dan tidak boleh lemah serta pembahasan dan atau pengaturan mengenai limbah B3 harus dipahami secara komprehensif.

Penegakan hukum pidana dalam rangka eksekusi barang bukti limbah Bahan Berbahaya Beracun (B3) harus sesuai dengan peraturan perundang-undangan mengenai lingkungan hidup, keberhasilan nya sangat diharapkan karena pada bidang penegakan hukum inilah dipertaruhkan makna dari "negara berdasarkan atas hukum". 7 Jaksa sebagai eksekutor mengalami kesulitan melaksanakan putusan hakim yang telah berkekuatan hukum tetap bila limbah B3 tersebut dirampas untuk dimusnahkan maka berpotensi mencemari lingkungan hidup kembali.

Bahwa pihak yang melakukan pengelolaan limbah Bahan Berbahaya Beracun (B3) wajib mempunyai izin pengelolaan limbah Bahan Berbahaya Beracun (B3), setiap penghasil limbah B3 wajib melakukan pengelolaan, dan setiap dumping (pembuangan) limbah B3 wajib dilengkapi dengan izin, dalam izin tersebut mensyaratkan kewajiban-kewajiban teknis pemegang izin untuk mengedepankan perlindungan lingkungan hidup. Instrumen perizinan ini sebenarnya ditujukan pada pencegahan atau penanggulangan pencemaran oleh intalasi terutama perusahaan industri. Berlakunya Undang-Undang Perlindungan dan Pengelolaan Lingkungan Hidup kompleksitas masalah perizinan lingkungan tetap saja tidak terselesaikan. Terbukti dari rumusan Pasal 18 ayat (2) UUPPLH : izin melakukan kegiatan diberikan pejabat yang berwenang sesuai dengan peraturan perundang-undangan yang berlaku. ${ }^{8}$

\footnotetext{
${ }^{6}$ http://www.menlh.go.id/berita Kemajuan Penanganan Pidana Kasus Impor Limbah B3 di Pulau Galang Baru Batam dikunjungi pada tanggal 12 Agustus 2018.

7 Muladi, Kapita Selekta Sistem Peradilan Pidana (Badan Penerbit Undip 1995).[8].

8 Siti Sundari Rangkuti, Op.Cit.[121-122].
} 
Fakta di lapangan berkata lain, banyak pelaku yang melakukan pengelolaan limbah Bahan Berbahaya Beracun (pengurangan, penyimpanan, pengumpulan, pengangkutan, pemanfaatan, pengolahan, dan/atau penimbunan) enggan melengkapinya dengan izin pengelolaan limbah B3, kemudian pelaku yang menghasilkan limbah B3 juga enggan melakukan pengelolaan limbah B3 dengan alasan akan memakan banyak biaya jika harus mengolah sendiri karena harus dilengkapi dengan izin pengolahan limbah B3 dimana untuk mengurusnya sulit dan memakan banyak biaya, dan jika akan diserahkan kepada pihak lain yang telah memiliki izin pemanfaatan/pengumpulan limbah B3 juga harus mengeluarkan banyak biaya juga, sehingga fakta dilapangan banyak penghasil limbah B3 yang langsung membuang limbah B3 yang dihasilkannya ke media lingkungan hidup tanpa izin.

Kejaksaan sebagai salah satu komponen Criminal Justice System mempunyai peran sentral dalam penegakan hukum yaitu sebagai dominus litis $^{9}$ sebagai pelaksana fungsi penuntutan dapat secara efektif menilai ketentuan pidana mana yang akan digunakan dalam menuntut suatu perkara tindak pidana lingkungan sekaligus sebagai eksekutor dalam melaksanakan putusan hakim yang berkekuatan hukum tetap (inkracht van gewijsde).

Penanganan barang bukti Tindak Pidana Lingkungan Hidup yang tidak profesional mengakibatkan lingkungan hidup terkontaminasi limbah B3 dan berdampak antara lain pencemaran atau perusakan lingkungan hidup kembali apabila barang bukti berupa limbah atau Bahan Berbahaya Beracun (B3) tersebut rusak, hilangnya atau mencemari lingkungan sekitar. Barang bukti limbah B3 yang disita dalam perkara juga menimbulkan resiko hukum bagi Penyidik dan Penuntut Umum bila selama proses perkara berlangsung tidak dikelola dengan baik, padahal untuk dapat mengeksekusi perkara tersebut Jaksa harus menunggu sampai putusan telah memperoleh kekuatan hukum tetap.

Persoalan mengenai barang bukti limbah Bahan Berbahaya Beracun (B3) yang merupakan benda yang disita untuk keperluan proses peradilan tidak dapat

9 Jan Marinka, Reformasi Kejaksaan dalam Sistem Hukum Nasional (Sinar Grafika, 2018).[8]. 
dibawa atau disimpan Rumah Penyimpanan Benda Sitaan Negara karena bersifat infeksius, beracun dan mudah terbakar dan meledak sedangkan menurut Pasal 44 ayat (1) UU RI No. 8 tahun 1981 tentang KUHAP jo Pasal 27 ayat (1) PP No. 27 Tahun 1983 tentang peraturan pelaksana KUHAP benda sitaan harus disimpan dalam rumah barang benda sitaan negara, yang disebut RUPBASAN.

Hakim dalam memutus barang bukti limbah B3 yang diimpor dari negara lain seharusnya putusannya dikembalikan ke negara asal (reekspor) oleh Pemerintah Indonesia ke negara asal dengan biaya dari terdakwa/importir. Seringkali utusan hakim mengenai barang bukti adalah dirampas untuk dimusnahkan hal tersebut akan mencemari lingkungan hidup kembali dan tidak sesuai dengan penegakan hukum lingkungan di Indonesia.

\section{Peran Jaksa sebagai Eksekutor Perkara Tindak Pidana Lingkungan Hidup Terkait Limbah Bahan Berbahaya Beracun agar Tidak Mencemari Lingkungan Kembali}

Kasus importir limbah bahan berbahaya beracun (B3) dari Korea yang dibuang di sungai Romokalisari Surabaya dan kasus 113 kontainer steel scrap milik PT. HHS yang mengandung limbah bahan berbahaya beracun (B3) membuat penyidik melakukan tindakan mengembalikan atau mereekspor ke negara asal atau negara tujuan yaitu Inggris dan Belanda dengan biaya ditanggung importir.

Sebelumnya, sebanyak 89 kontainer steel scrap yang bercampur dengan limbah B3 telah dikembalikan ke Felixtowe Inggris dengan disaksikan oleh Menteri Keuangan dan Menteri Lingkungan Hidup sesuai dengan Peraturan Menteri Perdagangan Nomor 39/M-DAG/PER/9/2009 ketentuan Impor Limbah Non Bahan Berbahaya Beracun (Non B3) dan Pengakuan Limbah Non B3 (IP-Limbah Non B3). Kedua kasus diatas maka dikatakan penegakan hukum lingkungan berkaitan erat dengan kemampuan aparaturnya dan kepatuhan masyarakat/ badan usaha terhadap peraturan perundang-undangan.

Kewenangan penyidik/PPNS tersebut ada dalam asas Tanggung Jawab Negara (state responsibility principle) sebenarnya merupakan salah satu prinsip hukum 
umum (general principles of law) dalam hukum lingkungan internasional yang bersumber dari prinsip-prinsip hukum Eropa Barat ${ }^{10}$ dan termasuk dalam prinsip yang bersifat pencegahan (prevention principle). Prinsip tanggung jawab negara ini sebenarnya memiliki dimensi memberikan tanggung jawab kepada negara untuk memastikan bahwa aktivitas dalam yurisdiksinya tidak akan menyebabkan kerusakan lingkungan di negara-negara lainnya atau kawasan di luar batas yurisdiksi nasional, bahkan dimulai dari awal perkara tanpa menunggu putusan pengadilan. Dalam penjelasan Pasal 2 huruf a UUPPLH, yang dimaksud dengan "asas tanggung jawab negara" antara lain adalah hak warga negara atas lingkungan hidup yang baik dan sehat harus dijamin oleh negara atau pemerintah. Di sini berarti pemerintah mempunyai kewajiban mencegah dilakukannya kegiatan yang menimbulkan pencemaran dan/atau kerusakan lingkungan hidup.

Karena masih tanggung jawab negara maka penegakan hukum lingkungan melibatkan sub sistem dalam sistem peradilan pidana di dalamnya termasuk polisi, jaksa, hakim, dan bapas. Kewenangan dalam sub sistem adalah melakukan pencegahan dapat menjalankan fungsi kelestarian lingkungan tanpa adanya resiko mencemari lingkungan kembali. Tindakan mengembalikan limbah B3 ke negara asal merupakan upaya pencegahan yang lebih cepat dan efisien. Menurut Philippe Nonet : " Hukum bukanlah apa yang para yuris anggap sebagai aturan yang mengikat atau aturan wajib, melainkan lebih dari itu, hukum adalah pengaturan-pengaturan konkret yang dilakukan oleh para hakim, polisi, jaksa ataupun pejabat administrasi". ${ }^{11}$

Substansi pembuktian berorientasi pada pemaparan dan evaluasi fakta untuk mendasari konstruksi putusan hakim secara meyakinkan. Fungsi utama investigasi ${ }^{12}$ maupun penuntutan delik lingkungan (pencemaran lingkungan) dan proses perkaranya di pengadilan adalah memeriksa fakta dan bukan hukumnya. Kebenaran fakta harus

\footnotetext{
${ }^{10}$ Adji Samekto, Negara Dalam Dimensi Hukum Internasional (Citra Aditya Bakti 2009). [55].

${ }^{11}$ Achmad Ali, Menguak Teori Hukum (Legal Theory) dan Teori Peradilan (Judicalprudence) (Kencana Prenada Media 2012).[56].

${ }^{12}$ G.A. Biezeveld, Criminal Enforcement of Environmental Law: general introduction, investigation and prosecution (Dutch Side): Part One: general introduction on environmental crimanal law enforcement, CELA, Sukabumi, 19-24 Februari 2001.
} 
ditemukan dalam mekanisme peradilan pidana agar hakim dapat memilih hukum yang tepat (in abstracto) untuk membuat putusan (in concreto) yang executable. ${ }^{13}$

Pada perkara limbah B3, putusan hakim harus memuat tindakan yang dijatuhkan terhadap terdakwa, status benda sitaan / limbah B3 yang dijadikan barang bukti dalam perkara tersebut dan biaya perkara. Ketentuan Pasal 194 ayat (1) KUHAP menentukan bahwa : "Dalam hal putusan pemidanaan atau bebas atau lepas dari segala tuntutan hukum pengadilan menetapkan supaya barang bukti yang disita diserahkan kepada pihak yang paling berhak menerima kembali yang namanya tercantum dalam putusan tersebut, kecuali jika menurut ketentuan Undang-Undang barang bukti itu harus dirampas untuk kepentingan negara atau dimusnahkan atau dirusak sehingga tidak dapat dipergunakan lagi." Walaupun Putusan hakim yang berkenaan dengan barang bukti dalam ptrakteknya hanya dikembalikan kepada pihak yang paling berhak, dirampas untuk kepentingan negara atau dimusnahkan atau dirusak dan barang bukti diperlukan dalam perkara lain maka khusus dalam perkala lingkungan diperlukan peraturan lain secara konkrit mengenai cara pemusnahan barang bukti limbah B3.

Adanya kekosongan hukum karena eksekusi mengenai barang bukti termasuk limbah B3 tidak dibahas dalam KUHAP maupun Undang-Undang Nomor 32 Tahun 2009 tentang Perlindungan dan Pengelolaan Lingkungan Hidup, aparat penegak hukum yang menangani perkara terkait limbah B3 harus tetap memperhatikan asas-asas yang ada dalam UUPPLH, sedangkan pelaksanaan eksekusi barang bukti terkait limbah B3 oleh jaksa dilakukan sesuai bunyi amar putusan hakim, pelaksanaannya harus dilakukan namun petunjuk pelaksanaannya berstandar dan mekanisme belum ditentukan dalam KUHAP maupun peraturan Mahkamah Agung atau SOP (Standar Operasional Prosedur) dari Kejaksaan RI sebagai bantuan bagi jaksa dalam melakukan eksekusi limbah B3.

Dari uraian diatas diperoleh kenyataan bahwa jaksa dalam kedudukannya sebagai pihak yang mengeksekusi hakim pidana kerap menemui kesulitan dalam

${ }^{13}$ George White Paton, A Text-Book of Jurisprudence (Oxford at the Clarendon Press, Amen House 1955 ).[155]. 
mengekskusi barang bukti. Kesulitan tersebut berpangkal dari kekosongan hukum mengenai mekanisme dan prosedur pelaksanaan eksekusi barang bukti, khususnya terhadap barang bukti Bahan Berbahaya Beracun (B3). Untuk barang bukti yang tidak menemui kesulitan karena Undang-Undang mengatur secara jelas. Kekosongan pengaturan khusus mengenai barang bukti Bahan Berbahaya Beracun (B3) berpotensi menimbulkan kekacauan di dalam lapangan hukum eksekusi putusan.

Undang-Undang Nomor 32 Tahun 2009 terdapat aturan bagi setiap orang yang melakukan pencemaran dan/atau perusakan lingkungan hidup yaitu dengan wajib melakukan penanggulangan pencemaran dan/atau kerusakan lingkungan hidup serta pemulihan fungsi lingkungan hidup. Penghentian sumber pencemaran dan/ atau kerusakan lingkungan hidup, rehabilitasi atau restorasi yang terdapat dalam Pasal 53-54 UUPPLH diterapkan oleh MA dalam putusan kasasi terhadap PT. Indo Bharat Rayon yang terbukti secara sah melakukan tindak pidana lingkungan dengan pidana denda Rp. 2 Milyar dan pidana tambahan melakukan pemulihan atau pembersihan rawa kali mati dari limbah Bahan Berbahaya Beracun (B3) ke kondisi semula. Tentunya eksekusi dari jaksa adalah menjalankan putusan hakim yang telah berkekuatan hukum tetap tersebut sesuai dengan tata cara pemulihan fungsi lingkungan hidup dalam peraturan pemerintah.

Eksekusi tindak pidana lingkungan hidup terkait limbah B3 harus sesuai dengan teori keseimbangan. Sistem hukum Indonesia mengenal pandangan yang dikemukakan oleh Didik Endro Purwoleksono yang mengemukakan bahwa tujuan pemidanaan dibagi menjadi 4 (empat) golongan yakni teori absolut atau teori pembalasan, teori relative atau teori tujuan, teori gabungan dan teori keseimbangan. ${ }^{14}$ Adapun pokok pemikiran teori keseimbangan yang dapat diadopsi hakim dalam memutus barang bukti terkaitlimbah B3 adalah tidak mengabaikan hak-hak korban dari tindak pidana lingkungan yaitu manusia dan makhluk hidup sekitarnya. Penuntut umum dalam mengajukan tuntutan kepada terdakwa juga mempertimbangkan masalah tuntutan mengenai barang

${ }^{14}$ Didik Endro Purwoleksono, Hukum Pidana (Airlangga University Press 2013).[92-94]. 
bukti limbah B3 dengan memperhatikan kepentingan korban yaitu manusia dan makhluk hidup sekitarnya.

Hakim memang corong dari undang-undang yang berisi aturan yang berfungsi mengatur masyarakat. Menurut Kelsen, hukum adalah sebuah sistem norma. Norma adalah pernyataan yang menekankan aspek "seharusnya" atau das sollen, dengan menyertakan beberapa peraturan tentang apa yang harus dilakukan. Namun untuk menuju hukum yang das sein maka norma-norma adalah produk dan aksi manusia yang deliberatif. Bila terdapat kekosongan hukum maka adanya pelaksanaan aturan tersebut menimbulkan kepastian hukum. ${ }^{15}$

Analisis beberapa putusan pengadilan berkaitan dengan eksekusi putusan limbah B3 Kedua putusan tersebut di atas memiliki perbedaan yaitu untuk putusan perkara Putusan Pengadilan Nomor 113/Pid.B/LH/2016/PN.Pwk terdakwa PT Indo Bharat Rayon yang diwakili oleh Sibnath Agarwalla selaku Direktur Finance PT Indo Bharat Rayon menjatuhkan putusan mengenai barang bukti terkait Bahan Berbahaya Beracun (B3) dirampas untuk dimusnahkan karena barang bukti yang diajukan oleh Penuntut Umum di depan persidangan sudah selesai digunakan dalam pembuktian perkara dan tidak ada keperluan pemeriksaan laboratorium kembali serta sudah tidak memiliki nilai ekonomis lagi maka harus dinyatakan dirampas untuk dimusnahkan. Bahwa karena seluruh barang bukti tersebut sudah selesai digunakan dalam pemeriksaan perkara ini, dan tidak dapat diambil nilai ekonomisnya dengan cara dijual lelang, maka hakim menyatakan barang bukti tersebut dirampas untuk dimusnahkan.

Untuk Putusan Nomor 2560 K/PID.SUS.LH/2015 atas nama Terdakwa PT. KOYAMA CASTING INDONESIA (PT. KCI) yang dalam hal ini diwakili oleh Shigemi Koyama, putusan judex factie terkait barang bukti Gram Besi sebanyak 500 (lima ratus) ton yang terbagi dalam 2 (dua) jenis limbah gram besi basah 100 (seratus) ton dan limbah gram besi kering 400 (empat ratus) ton dirampas dan dilelang untuk negara, Penuntut Umum keberatan atas putusan Majelis Hakim

\footnotetext{
${ }_{15}$ Peter Mahmud Marzuki, Pengantar Ilmu Hukum (Kencana Prenada Media Group 2008).[158].
} 
Pengadilan Negeri Karawang vide Pengadilan Tinggi Bandung yang menetapkan barang bukti tersebut dirampas dan dilelang oleh negara, dalam memori banding dan memori kasasi Jaksa/Penuntut Umum memberikan alasannya terkait barang bukti karena setelah Majelis Hakim Pengadilan Negeri Karawang beserta Jaksa Penuntut Umum yang disaksikan sendiri oleh terdakwa melakukan persidangan di Lokasi Penyimpanan Limbah B3 di PT. KOYAMA CASTING INDONESIA (PT. KCI) barang bukti tersebut sudah lengket dan karatan sehingga tidak dimungkinkan untuk dipergunakan kembali dan dapat membahayakan lingkungan sehingga Jaksa/Penuntut Umum menuntut supaya barang bukti tersebut dirampas untuk dimusnahkan sesuai dengan tuntutan Jaksa, namun permohonan Jaksa/Penuntut Umum tersebut ditolak dan memerintahkan barang bukti untuk dirampas dan dilelang untuk negara. Hal tersebut bertentangan dengan aturan dalam Pasal 45 KUHAP ayat (4) menyebutkan bahwa benda sitaan yang bersifat terlarang atau dilarang tidak termasuk dalam ketentuan ayat (1), dirampas untuk dipergunakan bagi kepentingan negara atau untuk dimusnahkan.

Barang bukti yang dalam amar putusannya dirampas untuk dimusnahkan dalam putusan Nomor 113/Pid.B/LH/2016/PN.Pwk dengan pertimbangan seluruh barang bukti tersebut sudah selesai digunakan dalam pemeriksaan perkara, khususnya untuk keperluan pemeriksaan laboratorium dan sudah tidak memiliki nilai ekonomis lagi, akan menimbulkan akibat pencemaran lingkungan kembali bila dalam pertimbangannya hakim tidak menjelaskan bahwa dirampas untuk dimusnahkan tersebut harus sesuai dengan peraturan yang berlaku dan dilakukan oleh pihak yang memperoleh izin dalam pemusnahan limbah B3 serta memiliki teknologi pemanfaatan limbah B3, yang semua hal tersebut dibawah pengawasan Jaksa/Penuntut Umum sebagai eksekutor dan hakim yang memutus perkara tersebut agar para aparat penegak hukum yang menangani kasus lingkungan terhindar dari perusakan dan pencemaran lingkungan kembali.

Pertimbangan hakim tersebut dalam memutuskan barang bukti seharusnya mengkaitkandenganprinsip-prinsipDeklarasiRio 1992, yaituasaspertanggungjawaban negara, keterpaduan, kehati-hatian (precautionary principle), keadilan, pencemar 
membayar (pollutan pays principle), partisifatif dan kearifan lokal (local wisdom principle). Pengadopsian ini adalah merupakan politik hukum yang penting karena dapat memperkuat kepentingan pengelolaan lingkungan hidup manakala berhadapan dengan kepentingan ekonomi jangka pendek, sehingga hakim dalam mengadili perkara-perkara lingkungan hidup dapat menggunakan prinsip-prinsip tersebut untuk memberikan perhatian atas kepentingan pengelolaan lingkungan hidup yang tidak diperhatikan oleh pelaku usaha atau pengurus badan usaha.

Berdasarkan politik hukum lingkungan hidup maka putusan terkait barang bukti harus dijatuhkan secara pro natura (pro lingkungan hidup) baik terhadap setiap putusan yang terbukti maupun yang tidak terbukti bersalah, namun bila hasil laboratorium menunjukkan barang bukti tersebut mengandung Bahan Berbahaya Beracun (B3) maka putusan hakim sebaiknya adalah barang bukti yang mengandung B3 dari negara lain tersebut dilakukan Re-Ekspor ke Negara asal dengan biaya dibebankan pada terdakwa sebagai impotir misalnya karena Indonesia bukan tempat pembuangan limbah B3, Undang-Undang Nomor 32 Tahun 2009 telah tegas melarang perbuatan tersebut sebagaimana dalam Pasal 69 ayat (1) huruf c dan d. Bila barang bukti limbah B3 bukan dari perkara ekspor impor maka putusan hakim seharusnya dirampas untuk dimusnahkan oleh pihak ketiga yang mempunyai ijin dalam pengelolaan/pemusnahan limbah B3 dengan biaya dari terdakwa agar tidak memberatkan eksekutor (keuangan negara).

Mengenai pertimbangan hakim akan perbuatan terdakwa yang dapat merusak lingkungan hidup dengan memperhatikan keadilan yang berlaku menurut hukum dan rasa keadilan yang ada dalam masyarakat maka majelis hakim dalam menjatuhkan putusan mengenai barang bukti B3 akan sesuai dengan prinsip-prinsip hukum untuk perlindungan lingkungan dan pembangunan sehingga termuat amar putusan yang dirasa adil dan seimbang bagi lingkungan hidup termasuk makhluk hidup yang ada di dalamnya. Hakim memegang tanggung jawab negara (state responsibility) untuk menstrukturkan seluruh proses eksekusi oleh Jaksa/Penuntut Umum sehingga peranan hukum yaitu menjamin adanya kepastian hukum dapat tercapai. 


\section{Kesimpulan}

Eksekusi terhadap putusan tindak pidana lingkungan hidup terkait Limbah Bahan Bahaya Beracun (B3) yang dilakukan Jaksa sebagai eksekutor harus dengan cara tidak pencemaran lingkungan kembali. Jika putusan hakim terkait barang bukti limbah B3 adalah dirampas untuk dimusnahkan maka Jaksa dapat melakukan upaya hukum banding dengan alasan putusan tersebut tidak sesuai dengan Peraturan perundang-undangan mengenai limbah B3 antara lain Undang-Undang Nomor 32 Tahun 2009 tentang Perlindungan dan Pengelolaan Lingkungan Hidup serta Peraturan Pemerintah Nomor 101 Tahun 2014 tentang Pengelolaan Limbah B3. Namun jika putusan yang berkekuatan hukum tetap tetap menyatakan dirampas untuk dimusnahkan maka eksekutor harus segara melaksanakan putusan tersebut.

Terlihat dalam putusan tindak pidana limbah Bahan Berbahaya Beracun (B3) dalam Putusan Pengadilan Nomor 113/Pid.B/LH/2016/PN.Pwk. atas nama terdakwa PT. Indo Bharat Rayon dan Putusan Pengadilan Nomor 2560 K/PID. SUS.LH/2015 atas nama terdakwa PT. Koyama Casting Indonesia, Hakim tidak mempertimbangkan keterangan dari beberapa saksi, ahli dan hasil laboratorium bahwa barang bukti limbah B3 tersebut dapat membahayakan bagi lingkungan hidup dan kesehatan manusia, dalam putusan hakim dan pertimbangan hakim mengenai barang bukti limbah B3 adalah dirampas dan dimusnahkan dan dirampas untuk negara hal tersebut tidak sesuai dengan asas keberlanjutan (sustainable development) dalam Undang-Undang Nomor 32 Tahun 2009 tentang Perlindungan dan Pengelolaan Lingkungan Hidup.

\section{Daftar Bacaan}

\section{Buku}

Achmad Ali, Menguak Teori Hukum (Legal Theory) dan Teori Peradilan (Judicalprudence) (Kencana Prenada Media 2012).

Adji Samekto, Negara Dalam Dimensi Hukum Internasional (Citra Aditya Bakti 2009).

Agoes Soegianto, Ilmu Lingkungan, Sarana Menuju Masyarakat Berkelanjutan 
(Airlangga University Press 2012).

Amirudin A. Dajaan Imami, dkk, Asas Subsidaritas : Kedudukan dan Implementasi dalam Penegakan Hukum Lingkungan (PP-PSL FH UNPAD dan Bestar 2009).

Andi Hamzah, Penegakan Hukum Lingkungan, Environmental Law Enforcement (Alumni Jakarta, 2016).

Didik Endro Purwoleksono, Hukum Pidana (Airlangga University Press 2013).

Gustav Radburch, Vorschule der Rechtsphilosophie dikutip Satjipto Rahardjo, Penegakan Hukum Suatu Tinjauan Sosiologis (Genta Publishing 2009).

Guyer, Allen W. Wood, Immanuel Kant, Critique of Pure Reason Cambridge (University Press 1998).

Jan Marinka, Reformasi Kejaksaan dalam Sistem Hukum Nasional (Sinar Grafika, 2018).

Jimly Asshiddiqie, Green Constitution, Nuansa Hijau Undang-Undang Dasar Negara Republik Indonesia Tahun 1945 (Raja Grafindo Persada 2009).

Muladi, Kapita Selekta Sistem Peradilan Pidana (Badan Penerbit Undip 1995).

Mohammad Rozi, Pertanggungjawaban Pidana Penebangan Pohon Secara Liar (Illegal Loging) (Miswar 2015).

M. Syukri Akub dan Baharuddin Baharu Wawasan Due Process of Law Dalam Sistem Peradilan Pidana editor Amir Ilyas Yogyakarta (Mahakarya Rangkang Offset 2012).

Melda Kamil Ariadno, Hukum Internasional Hukum yang Hidup (Diadit Media 2007).

M. Daud Silalahi, Pengaturan Hukum Sumber Daya Air dan Lingkungan Hidup di Indonesia (Almni Bandung 2003).

M. Daud Silalahi, Hukum Lingkungan Dalam Perkembangan di Indonesia (Almni Bandung 2003).

Muhammad Erwin, Hukum Lingkungan Dalam Sistem Kebijaksanaan Pembangunan Lingkungan Hidup (Refika Aditama 2009).

Muhammad Erwin, Hukum Lingkungan Dalam Sistem Perlindungan dan 
Pengelolaan Lingkungan Hidup di Indonesia Edisi Revisi (Refika Aditama 2009).

Peter Mahmud Marzuki, Pengantar Ilmu Hukum (Kencana Prenada Media Group 2008).

George White Paton, A Text-Book of Jurisprudence, (Oxford at the Clarendon Press Amen House 1955).

Siti Sundari Rangkuti, Hukum Lingkungan dan Kebijaksanaan Lingkungan Nasional (Airlangga University Press 2015).

Syamsuharya Bethan, Penerapan Prinsip Hukum Pelestarian Fungsi Lingkungan Hidup Dalam Aktivitas Industri Nasional Sebuah Upaya Penyelamatan Lingkungan Hidup dan Kehidupan Antar Generasi (Alumni 2008).

\section{Perundang-undangan}

Undang-Undang Dasar Negara Republik Indonesia Tahun 1945.

Undang-Undang Republik Indonesia Nomor 8 Tahun 1981 tentang Hukum Acara Pidana.

Undang-Undang Republik Indonesia Nomor 16 Tahun 2004 tentang Kejaksaan.

Undang-Undang Republik Indonesia Nomor 32 Tahun 2009 tentang Perubahan atas Undang-Undang Republik Indonesia Nomor 23 Tahun 2007 Tentang Perlindungan dan Pengelolaan Lingkungan Hidup.

Peraturan Pemerintah No. 101 Tahun 2014 tentang Pengelolaan Limbah B3.

\section{Jurnal}

G.A. Biezeveld, 'Criminal Enforcement of Environmental Law : general introduction, investigation and prosecution (Dutch Side) : Part One : general introduction on environmental crimanal law enforcement' CELA, (2001).

G.H. Addink, Penataran Environmental Law and Suistainable Development: Literature, (Surabaya: Fakultas Hukum Universitas Airlangga, 1999), h. 35; Lihat juga Siti Sundari Rangkuti, Op Cit.[379]; Siti Sundari Rangkuti, "Kesamaan Persepsi Terhadap Penegakan Hukum Lingkungan", Yuridika, No. 5 Tahun IX September-Oktober 1994, [3, 4]; Muhammad Akib, Hukum Lingkungan, Perspektif Global dan Nasional (Rajawali Pers, Edisi Revisi, Cetakan Kedua, Oktober 2014). 


\section{Laman}

http:/www.nasional.tempo.co/berita/baca Indonesia Jadi Importir Limbah B3 dikunjungi pada tanggal 19 Agustus 2018.

http://www.menlh.go.id/berita Kemajuan Penanganan Pidana Kasus Impor Limbah B3 di Pulau Galang Baru Batam dikunjungi pada tanggal 12 Agustus 2018.

HOW TO CITE: Ika Mauluddhina, 'Eksekusi Putusan Tindak Pidana Lingkungan Hidup Terkait Limbah Bahan Berbahaya Beracun (B3)' (2019) Vol. 2 No. 1 Media Iuris. 
--Halaman ini sengaja dikosongkan-- 